\title{
Mortality of sea scallops Placopecten magellanicus in the Mid-Atlantic Bight: Comment on Stokesbury et al. (2011)
}

\author{
Deborah R. Hart* ${ }^{*}$ Burton V. Shank \\ Northeast Fisheries Science Center, 166 Water St., Woods Hole, Massachussetts 02543, USA
}

\begin{abstract}
Stokesbury et al. (2011; Mar Ecol Prog Ser 425:167-173) concluded that 10 billion sea scallops Placopecten magellanicus probably died from discarding during fishing operations between surveys in 2003 and 2004, based on the observed reduction in scallops between these 2 surveys. The reported mortality primarily occurred in a very large 2001 year class that was below commercial size in 2003-2004, whereas mortality rates were lower for larger commercial-sized scallops. This pattern is not consistent with mortality from discarding, because commercial scallop dredge gear is designed to retain commercial-sized scallops, allowing a substantial proportion of undersized scallops to escape through the dredge rings. Data from at-sea observers in the MidAtlantic indicate that only 319 million scallops were discarded during this period. Non-capture (incidental) fishing mortality was also too low to account for the observed mortality. However, juvenile scallop mortality due to predation increases with their density, primarily induced by crabs Cancer spp. The observed high mortality of juvenile scallops was therefore probably a result of increased predation, rather than discarding.
\end{abstract}

KEY WORDS: Scallop - Cancer spp. · Predation - Fishery discards - Density dependence · Placopecten magellanicus

\section{Introduction}

Fishery discarding is an issue of serious concern, because it can lead to reductions in fishery yields and bycatch populations, and to alterations of marine food webs and ecosystems (Harrington et al. 2005). Accurate estimation of discards is therefore important for understanding the dynamics of the discarded species and the effects of fisheries on marine ecosystems.

Stokesbury et al. (2011) concluded that 10 billion sea scallops Placopecten magellanicus - over half of the entire estimated scallop population - were probably killed by being discarded during scallop fishery operations in the Mid-Atlantic Bight between 2003 and 2004. They based their conclusion on the observed substantial decline in sea scallop abundance between 2003 and 2004, which they attributed to discarding because other potential causes seemed unlikely. We show that (1) the pattern of mortality described by Stokesbury et al. (2011) is not consistent with high mortality due to discarding; (2) direct estimates of discarding from at-sea observers are more than an order of magnitude lower than the 10 billion discards suggested by Stokesbury et al. (2011); and (3) predation related to the extremely high juvenile scallop densities observed in 2003 is a likely and credible alternative explanation for the decline. 


\section{Patterns of mortality}

Sea scallop dredges are designed to retain scallops larger than the dredge ring size (89 $\mathrm{mm}$ in 2003), while allowing a substantial proportion of smaller scallops to escape through the dredge rings (e.g. Yochum \& DuPaul 2008). Thus, even under the unlikely scenario that all discarded scallops die, the fishing mortality rate of small scallops due to dredge capture cannot exceed the mortality rate of scallops larger than the dredge ring size. However, it is evident from Fig. 4 of Stokesbury et al. (2011) that there was a much greater proportional reduction in the number of small scallops than large ones, indicating that the mortality rate was much higher for small scallops well below commercial size than it was for larger scallops. Even if the dredge was less selective for large scallops, e.g. because of dredge rings being clogged with scallops or debris, fishing-related mortality rates could still not be higher in small scallops than in large ones. Therefore, we find that the data in Stokesbury et al. (2011) are inconsistent with high mortality from discarding.

\section{Discard estimation from at-sea observers}

At-sea scientific observers on commercial scallop vessels report on the quantity and shell heights of retained and discarded scallops (NEFSC 2010). Based on 149 scallop trips in the Mid-Atlantic Bight between July 2003 and June 2004, about 12\% (by weight; $\mathrm{SE}=1 \%$ ) of caught scallops were discarded. Less than $10 \%$ of the scallops caught in commercial scallop gear had <80 mm shell height, even though a large majority of the population was smaller than this size (Stokesbury et al. 2011, their Fig. 4, and our Fig. 1); therefore, fishery-related capture mortality was much lower for small scallops than for larger ones. Mid-Atlantic sea scallop landings during this period were $25432 \mathrm{t}$ of meat, implying that about $3408 \mathrm{t}$ of scallop meat was discarded, based on the fraction discarded on observation trips. Using a mean meat weight of discards of $10.7 \mathrm{~g}$ (estimated from the shell height of discards as measured by observers in our Fig. 1, and the shell height to meat weight relationship from NEFSC 2010), about 319 million scallops were discarded between July 2003 and June 2004. Thus, even if none of the discards survived, mortality due to discarding was much lower than that estimated in Stokesbury et al. (2011).

Although Murawski \& Serchuk (1989) observed $<10 \%$ mortality from discarding during the summer

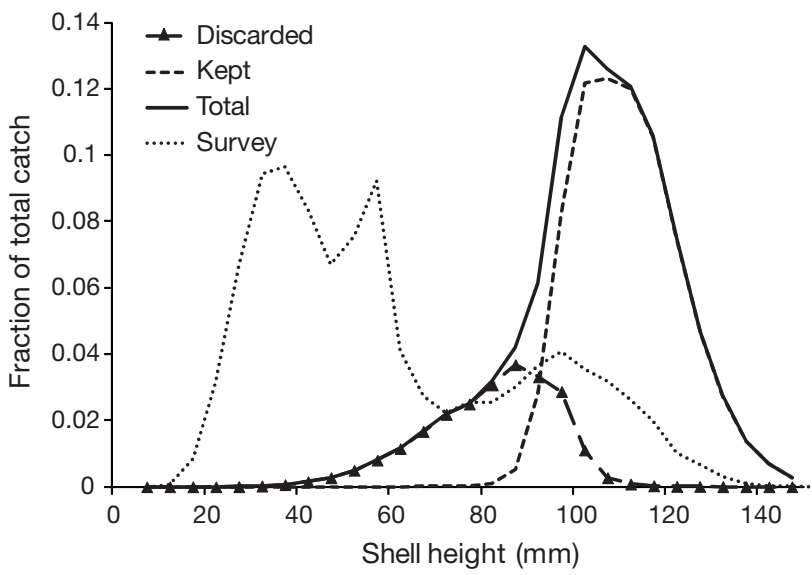

Fig. 1. Placopecten magellanicus. Shell height of sea scallops caught by commercial scallop vessels in the MidAtlantic Bight between July 2003 and June 2004, together with shell heights of discarded scallops and retained scallops, all based on data from 149 observed commercial trips. The dotted line gives shell heights from the 2003 NEFSC sea scallop survey in the Mid-Atlantic Bight, which uses a dredge with a $38 \mathrm{~mm}$ liner that catches smaller scallops than commercial gear, and is representative of the shell heights of the scallop population $>38 \mathrm{~mm}$

in the Mid-Atlantic, commercial fishing practices combined with high deck temperatures may induce high discard mortality rates during the warmest months, as hypothesized by Stokesbury et al. (2011). However, the fishery is conducted during all seasons, and it is likely that a higher percentage of discarded scallops survive during cooler weather. Thus, the number of scallops that died from discarding is likely considerably lower than 319 million ind.

\section{Estimates of incidental (non-capture) fishing mortality}

The term 'incidental fishing mortality' usually applies to non-capture fishing mortality, caused by gear crushing scallops or other forms of physical damage, rather than from discarding (e.g. Caddy 1973, Hart 2003). Direct observations in the MidAtlantic Bight found that $<5 \%$ of the scallops remaining in dredge tracks appeared damaged by such processes (Murawski \& Serchuk 1989). Another way of evaluating the effect of fishing on small scallops is to examine the mean size frequency patterns of the population. When averaged over a number of years (to reduce artifacts due to individual year classes), the slope or trend of the number of scallops per shell height bin is an indicator of the level of mortality; low mortality rates are reflected in a steady to increasing trend, whereas a decreasing trend indicates higher mortality. Mean size frequency patterns of scallops 


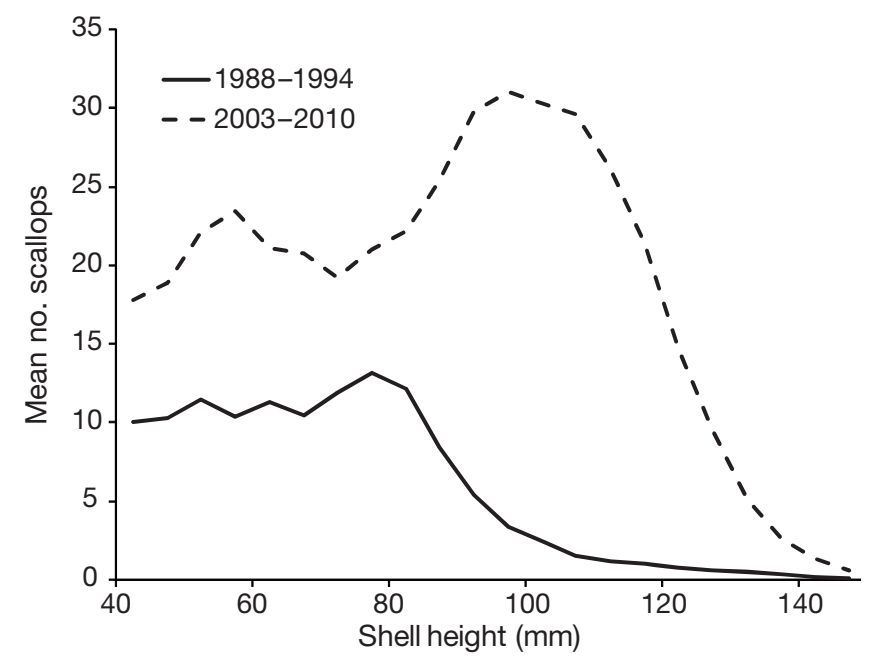

Fig. 2. Placopecten magellanicus. Mean numbers of sea scallops per $5 \mathrm{~mm}$ shell height bin in the Mid-Atlantic Bight from 1988 to 1994 and 2003 to 2010 (from NEFSC sea scallop surveys)

(Fig. 2) show a steady or slightly increasing trend at shell heights between 40 and $80 \mathrm{~mm}$ during both 1988-1994 (when fishing was most intensive) and the most recent period (2003-2010). During the 1988-1994 period, the numbers of scallops drastically declined at shell heights $\geq 80 \mathrm{~mm}$, whereas in the 2003-2010 period, scallop numbers increased at shell heights from 80 to $100 \mathrm{~mm}$, and only declined above $100 \mathrm{~mm}$. These differences are due to changes in fishery selectivity: 80 to $100 \mathrm{~mm}$ scallops were intensively fished during 1988-1994, but few scallops smaller than $100 \mathrm{~mm}$ were landed during 2003-2010, due to changes in both dredge ring size and discarding practices (NEFSC 2010). Thus, these data (Fig. 2) indicate that the mortality of scallops of commercial size (>80 $\mathrm{mm}$ in 1988-1994 and >100 $\mathrm{mm}$ in 2003-2010) was much higher than that of those below commercial size and above $40 \mathrm{~mm}$ shell height. It can be concluded that discard and incidental fishing mortality of scallops between 40 and $100 \mathrm{~mm}$ shell height is much smaller than the direct (landed) fishing mortality of commercial-sized scallops, consistent with our evidence based on mortality patterns and at-sea observations. The high observed mortality in juvenile sea scallops during 2003-2004 could therefore not be primarily due to either discarding or to incidental fishing mortality.

\section{Density-dependence and predation mortality}

While the cause of the high scallop mortality during 2003-2004 may never be known with certainty, it is likely related to the extremely high density of the 2001 year class in the Elephant Trunk region off New Jersey and Delaware (Hart \& Rago 2006, NEFSC 2010, Stokesbury et al. 2011). The NEFSC sea scallop dredge survey has been conducted annually since 1979 (Hart \& Rago 2006, NEFSC 2010), and the mean catch from 5613 random stations in the Mid-Atlantic Bight sampled between 1979 and 2001 was 156 scallops tow ${ }^{-1}$, with a maximum of 8952 scallops tow ${ }^{-1}$. Large numbers of small scallops $\quad<25 \mathrm{~mm}$ shell height), approximately $1 \mathrm{yr}$ old, were observed in the 2002 survey in the Elephant Trunk region (Fig. 3); these observations underestimate the true population of this size, since a substantial percentage of these scallops would have passed through the survey dredge's 38 mm liner. In 2003, when most of the 2001

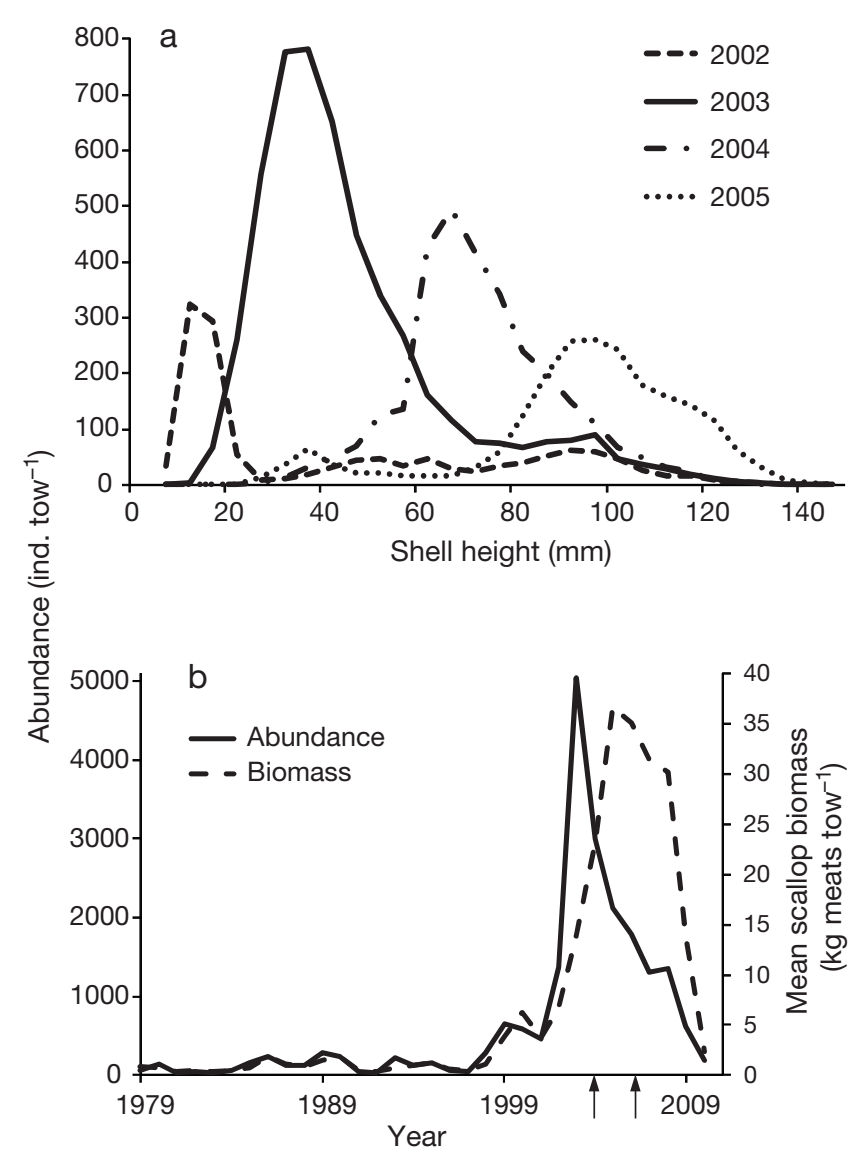

Fig. 3. Placopecten magellanicus. (a) Shell heights, in $5 \mathrm{~mm}$ bins, each year between 2002 and 2005 and (b) stratified mean abundance and biomass of sea scallops in the Elephant Trunk region (coasts of New Jersey and Delaware, USA) (based on NEFSC sea scallop surveys). Arrows delineate the fishery closure in 2004 and re-opening in 2007; note that the decline in abundance continued even after the area was closed to fishing in 2004, indicating that fishing was not the only contributor to the decline 
year class was large enough to be fully retained by the survey dredge, there was a very high abundance $\left(\right.$ mean $=5049$ scallops tow $\left.{ }^{-1}\right)$ in the Elephant Trunk region, similar to that reported by Stokesbury et al. (2011); this corresponds to a mean density of 2.8 ind. $\mathrm{m}^{-2}$ (assuming a $40 \%$ survey dredge efficiency; NEFSC 2010), which is over 25 times the mean density in this area from 1979 to 2001 (Fig. 3). The maximum catch during the NEFSC scallop survey in 2003 was 43212 scallops tow $^{-1}$, corresponding to a mean density of over 24 scallops $\mathrm{m}^{-2}$ over the $4500 \mathrm{~m}^{2}$ towpath. Stokesbury et al. (2011) report small-scale $\left(\sim 3 \mathrm{~m}^{2}\right.$ quadrat) densities exceeding 40 ind. $\mathrm{m}^{-2}$ in 2003.

Mortality from both disease and predation tend to be density-dependent. While we have no direct evidence of increased disease or parasitism during 2003 and 2004, diseases can cause substantial mortality on large year classes of scallops (e.g. Gulka et al. 1983). Predation rates on juvenile scallops can also be substantial and increase with scallop density, as demonstrated by seeding experiments (Cliche et al. 1994, Hatcher et al. 1996, Barbeau et al. 1996, 1998). For example, Wong et al. (2005) seeded juvenile scallops in experimental plots at densities of 1, 6 or 69 ind. $\mathrm{m}^{-2}$. Scallop density in the high-density sites declined markedly due to both predation and dispersal, resulting in final densities of about $1 \mathrm{~m}^{-2}$ regardless of treatment. This is consistent with observations in the Elephant Trunk region, where mean densities declined from 2.8 ind. $\mathrm{m}^{-2}$ in 2003 to 1.7 ind. $\mathrm{m}^{-2}$ in 2004 and 1.2 ind. $\mathrm{m}^{-2}$ in 2005 (Fig 3; note that the declines continued even after the Elephant Trunk area was closed to fishing in 2004). Predation rates of crabs Cancer spp. on clams and juvenile scallops increase with prey density (Boulding \& Hay 1984, Barbeau et al. 1998). When presented with alternative prey, C. irroratus primarily attacks the prey occurring at higher density (Wong \& Barbeau 2005). Thus, the high densities of juvenile scallops in the Elephant Trunk area may have induced increased predation by Cancer spp. Crab predation would explain the observed higher mortality rates in small compared to large scallops, since Cancer mostly consumes scallops $<70 \mathrm{~mm}$ in shell height (Elner \& Jamieson 1979, Lake et al. 1987).

Stokesbury et al. (2011) report mean sea scallop and Cancer densities of 5.28 and 0.05 ind. $\mathrm{m}^{-2}$, respectively, in the areas with highest recruitment in 2003 (presumably a portion of the Elephant Trunk region). At these densities, crabs could consume $60 \%$ of the scallops in the area in a year (corresponding to the observed decline, according to Stokesbury et al.
2011) at a per capita consumption rate of about 0.17 scallops $\mathrm{d}^{-1}$. Cancer crabs can consume more than 3 scallops ind. ${ }^{-1} \mathrm{~d}^{-1}$ in laboratory experiments (Nadeau et al. 2009). While this is not conclusive proof, the declines in scallop densities observed in the Mid-Atlantic Bight are consistent with densitydependent losses due to predation, and in particular to crab predation.

\section{Conclusions}

In highly fecund marine organisms such as sea scallops, mortality is very high during their larval and post-settlement juvenile stages (McGarvey et al. 1992, Gosselin \& Qian 1997, Hart 2006). Non-linear, rapidly saturating relationships between egg production and recruitment, as observed in sea scallops and many other marine species, indicate that there is strong intra-cohort density-dependent mortality at these early life-history stages (Shepherd \& Cushing 1980, NEFSC 2010). Predation is likely a major cause of mortality in juvenile sea scallops and many other species; functional or numerical responses of predators to high prey densities can thus explain the observed density-dependent juvenile mortality (e.g. Hixon \& Carr 1997, Wong \& Barbeau 2005, Wong et al. 2005). By contrast, scallop mortality due to fishing is typically higher at commercial sizes than in juveniles and depends on the level of fishing effort rather than being directly related to the density of the target species. Therefore, the high mortality of juvenile sea scallops observed between 2003 and 2004 by Stokesbury et al. (2011) was not primarily due to fishery discarding, but was likely mainly the result of densitydependent predation.

Acknowledgements. We thank L. Jacobson and A. Chute for comments on drafts of this article. B.V.S. was supported by a grant from NOAA's 'Fisheries and the Environment' program.

\section{LITERATURE CITED}

Barbeau MA, Hatcher BG, Scheibling RE, Hennigar AW, Taylor LH, Risk AC (1996) Dynamics of juvenile sea scallop (Placopecten magellanicus) and their predators in bottom seeding trials in Lunenburg Bay, Nova Scotia. Can J Fish Aquat Sci 53:2494-2512

Barbeau MA, Scheibling RE, Hatcher BG (1998) Behavioural responses of predatory crabs and sea stars to varying density of juvenile sea scallops. Aquaculture 169:87-98

Boulding EG, Hay TK (1984) Crab response to prey density can result in density-dependent mortality of clams. Can J Fish Aquat Sci 41:521-525

> Caddy JF (1973) Underwater observations on tracks of 
dredges and trawls and some effects of dredging on a scallop ground. J Fish Res Board Can 30:173-180

Cliche G, Giguère M, Vigneau S (1994) Dispersal and mortality of sea scallops, Placopecten magellanicus (Gmelin, 1791), seeded on the sea bottom off Îles-de-laMadeleine. J Shellfish Res 13:565-570

Elner RW, Jamieson GS (1979) Predation of sea scallops, Placopecten magellanicus, by the rock crab, Cancer irroratus, and the American lobster, Homarus americanus. J Fish Res Board Can 36:537-543

Gosselin LA, Qian PY (1997) Juvenile mortality in benthic marine invertebrates. Mar Ecol Prog Ser 146:265-282

Gulka G, Chang PW, Marti KA (1983) Prokaryotic infection associated with a mass mortality of the sea scallop, Placopecten magellanicus. J Fish Dis 6:355-364

Harrington JM, Myers RA, Rosenberg AA (2005) Wasted fishery resources: discarded by-catch in the USA. Fish Fish 6:350-361

Hart DR (2003) Yield- and biomass-per-recruit analysis for rotational fisheries, with an application to the Atlantic sea scallop (Placopecten magellanicus). Fish Bull 101: $44-57$

> Hart DR (2006) Effects of sea stars and crabs on sea scallop Placopecten magellanicus recruitment in the MidAtlantic Bight (USA). Mar Ecol Prog Ser 306:209-221

Hart DR, Rago PJ (2006) Long-term dynamics of U.S. Atlantic sea scallop Placopecten magellanicus populations. N Am J Fish Manage 26:490-501

Hatcher BG, Scheibling RE, Barbeau MA, Hennigar AW, Taylor LH, Windust AJ (1996) Dispersion and mortality of a population of sea scallop (Placopecten magellanicus) seeded in a tidal channel. Can J Fish Aquat Sci 53:38-54

Hixon MA, Carr MH (1997) Synergistic predation, density dependence, and population regulation in marine fish. Science 277:946-949

Lake NCH, Jones MB, Paul JD (1987) Crab predation on scallop (Pecten maximus) and its implication for scallop cultivation. J Mar Biol Assoc UK 67:55-64

McGarvey R, Serchuk FM, McLaren IA (1992) Statistics of

Editorial responsibility: Christine Paetzold,

Oldendorf/Luhe, Germany reproduction and early life history survival of the Georges Bank sea scallop (Placopecten magellanicus) population. J Northwest Atl Fish Sci 13:83-99

Murawski S, Serchuk F (1989) Environmental effects of offshore dredge fisheries for bivalves. ICES CM 1989/K:27

Nadeau M, Barbeau MA, Brêthes JC (2009) Behavioural mechanisms of sea stars (Asterias vulgaris Verrill and Leptasterias polaris Müller) and crabs (Cancer irroratus Say and Hyas araneus Linnaeus) preying on juvenile sea scallops (Placopecten magellanicus (Gmelin)), and procedural effects of scallop tethering. J Exp Mar Biol Ecol 374:134-143

NEFSC (Northeast Fisheries Science Center) (2010) Atlantic sea scallop stock assessment for 2010. In: 50th Northeast regional stock assessment workshop (50th SAW) assessment report. Ref Doc 10-17, US Dept Commerce, Northeast Fisheries Science Center, Woods Hole, MA, p 393-708

Shepherd JG, Cushing DH (1980) A mechanism for densitydependent survival of larval fish as the basis of a stockrecruitment relationship. ICES J Mar Sci 39:160-167

> Stokesbury KDE, Carey JD, Harris BP, O'Keefe CE (2011) Incidental fishing mortality may be responsible for the death of ten billion juvenile sea scallops in the midAtlantic. Mar Ecol Prog Ser 425:167-173

Wong MC, Barbeau MA (2005) Prey selection and the functional response of sea stars (Asterias vulgaris Verrill) and rock crabs (Cancer irroratus Say) preying on juvenile sea scallops (Placopecten magellanicus (Gmelin)), and blue mussels (Mytilus edulis Linnaeus). J Exp Mar Biol Ecol 327:1-21

- Wong MC, Barbeau MA, Hennigar AW, Robinson SMC (2005) Protective refuges for seeded juvenile scallops (Placopecten magellanicus) from sea star (Asterias spp.) and crab (Cancer irroratus and Carcinus maenas) predation. Can J Fish Aquat Sci 62:1766-1781

Yochum N, DuPaul WD (2008) Size-selectivity of the northwest Atlantic sea scallop (Placopecten magellanicus) dredge. J Shellfish Res 27:265-271

Submitted: October 7, 2011; Accepted: November 21, 2011 Proofs received from author(s): November 29, 2011 